\title{
EFEKTIFITAS METODE CERAMAH DAN BERMAIN DALAM PENYULUHAN KESEHATAN GIGI DAN MULUT TERHADAP PENGETAHUAN SISWA/I SD N 064026 LADANG BAMBU MEDAN TUNTUNGAN 2014
}

\author{
Ety Sofia Ramadhan \\ Politeknik Kesehatan Kemenkes Medan, Jurusan Keperawatan
}

\begin{abstract}
Abstrak
Umumnya pendidikan kesehatan gigi dan mulut diperoleh melalui penyuluhan. Kelompok masyarakat yang sering dituju adalah anak-anak sekolah dasar, karena usia 6-14 tahun tergolong usia rentan dan merupakan masa yang baik untuk meletakkan dasar-dasar pendidikan kesehatan. Ada beberapa metode penyuluhan diantaranya metode ceramah dan bermain yang bertujuan untuk meningkatkan pengetahuan tentang kesehatan gigi dan mulut pada siswa/i kelas V SD N 064026 Ladang Bambu, Medan Tuntungan. Penelitian ini bersifat analitik dengan menggunakan Uji T-tes, sampel adalah seluruh siswa/i kelas V SD N 064026 Ladang Bambu Medan Tuntungan yang berjumlah 60 0rang siswa/i. Dari hasil penelitian yang didapat rata-rata skor pengetahuan sebelum dilakukan penyuluhan kesehatan gigi dan mulut dengan metode ceramah adalah 10,87, dengan metode bermain adalah 13. Nilai rata-rata skor pengetahuan sesudah penyuluhan kesehatan gigi dan mulut dengan metode ceramah adalah 11,07. Dengan metode bermain adalah 14,3, kemudian dari hasil Uji statistik menunjukkan selisih skor rata-rata sebelum dan sesudah penyuluhan dengan metode ceramah adalah 2,3 dan selisih skor rata-rata sebelum dan sesudah penyuluhan dengan metode bermain sebesar 3,23 / $\mathrm{p}(0,016) ; \mathrm{p}<0,05$ secara statistik ada perbedaan yang bermakna. Dapat ditarik kesimpulan bahwa dari kedua metode penyuluhan yang digunakan dapat meningkatkan pengetahuan siswa/i tentang kesehatan gigi dan mulut namun metode bermain lebih efektif pada anak-anak dibandingkan dengan metode ceramah.
\end{abstract}

\section{PENDAHULUAN}

Kesehatan merupakan salah satu unsur dalam pembangunan nasional yang berguna untuk peningkatan dan pengembangan sumber daya manusia. Dengan masyarakat yang sehat, akan dapat mewujudkan derajat kesehatan yang optimal, dimana sehat menurut WHO adalah suatu keadaan jasmani, rohani dan sosial yang sempurna tidak hanya bebas dari penyakit, cacat dan kelemahan (Depkes RI 2010).

Dalam UU RI No.23 tahun 1992 tentang kesehatan menjelaskan untuk mewujudkan derajat kesehatan yang optimal bagi masyarakat diselenggarakan upaya kesehatan dengan pendekatan peningkatan (promotif), pencegahan penyakit (preventif), penyembuhan penyakit (kuratif) dan pemulihan kesehatan (rehabilitatif) yang dilaksanakan secara menyeluruh, terpadu dan berkesinambungan.

Untuk peningkatan pemanfaatan pelayanan kesehatan gigi dan mulut kepada masyarakat dan mewujudkan derajat kesehatan masyarakat yang optimal dalam mengembangkan Visi dan Misi Departemen Kesehatan 2010, maka peningkatan, pencegahan dan pemulihan kesehatan gigi dan mulut dipoliklinik Gigi sebagai unit pelayanan yang memberikan pelayanan dasar kepada masyarakat mutlak diperlukan (Dinkes Sul-Sel, 2001).

Kesehatan gigi dan mulut sebagai bagian integral dari pembangunan kesehatan semakin muncul dipermukaan. Pola hidup modern dengan konsumsi Refined Carbohydrate dan kesadaran tentang fungsi gigi dan mulut, serta transisi epidemiologi telah mendorong pemunculan kebutuhan pelayanan kesehatan gigi dan mulut. Sejalan dengan hal tersebut perlu dimantapkan langkah-langkah Depkes untuk tuntunan masyarakat dengan cara meratakan pelayanan kesehatan gigi dan mulut, sekaligus meningkatkan mutu pelayanan (Dirjen PMKG, 1998).

Penyuluhan kesehatan adalah kegiatan pendidikan kesehatan, yang dilakukan dengan meyebarkan pesan, menanamkan keyakinan, sehinga masyarakat tidak hanya sadar, tahu dan mengerti, tetapi juga mau dan mampu melakukan anjuran yang ada hubungannya dengan kesehatan. Penyuluhan juga merupakan suatu proses belajar non formal kepada sekelompok masyarakat tertentu, sehingga pada penyuluhan kesehatan gigi dan mulut diharapkan terciptanya suatu pengertian yang baik mengenai kesehatan gigi dan mulut. (Direktorat Kesehatan Gigi. Jakarta:1999:4-17).

Penyuluhan mempunyai efek terhadap anak-anak yang disuluh sehingga diharapkan akan terjadi perubahan 
tingkah laku yang meliputi aspek kognitif dan psikomotor (Gondhoyoewono. T 1997).

Menurut Rusli, 2003, pola penyuluhan kesehatan gigi dan mulut pada anak-anak lebih berhasil jika dilakukan dengan berpedoman pada proses belajar dan bermain. Oleh karena itu, metode bermain di anggap lebih efektif dibandingkan metode ceramah.

Hasil penelitian Makuch, 2001, juga membuktikan bahwa metode bermain dapat meningkatkan pengetahuan anak lebih baik dibandingkan dengan metode ceramah. Penelitian yang dilakukan oleh Fuller, 2001, pada anak-anak SD di Inggris, juga menunjukkan bahwa metode bermain telah menjadi pelopor kesehatan secara lisan dalam promosi kesehatan gigi dan mulut. Menurut Budiharto, 1998, penyuluhan memiliki beberapa metode, antara lain yaitu metode ceramah, diskusi, curah pendapat, panel, bermain, demonstrasi, simposium dan metode seminar dan metode yang paling sering digunakan adalah penyuluhan kesehatan gigi dan mulut dengan metode ceramah dan metode bermain. Metode bermain dianggap lebih efektif dan mempunyai nilai tambah dibandingkan dengan metode ceramah. Hal yang mendasari kegiatan penyuluhan dan pendidikan pada umumnya adalah proses belajar mengajar. Didalam proses belajar mengajar seorang pendidik (penyuluh) harus dapat memilih dan menggunakan metode mengajar yang cocok dan relevan.

Dilihat dari segi usia rentannya anak yang terkena penyakit, maka penyuluhan terutama ditujukan pada golongan yang rawan terhadap gangguan kesehatan gigi dan mulut yaitu anak sekolah dasar. Oleh karena usia 6-14 tahun merupakan usia transisi atau pergantian gigi desidui dengan gigi permanen (masa gigi bercampur). Disamping itu anak sekolah dasar kurang dapat menjaga kebersihan gigi dan mulut.

Dari latar belakang masalah di atas maka peneliti melakukan penelitian pada anak usia sekolah dasar untuk melihat efek penyuluhan dengan metode ceramah dan bermain dalam meningkatkan pengetahuan tentang kesehatan gigi dan mulut. Penelitian ini dilakukan pada siswa kelas V, karena munurut Gondhoyoewono secara psikologis anak kelas V SD sudah dapat menerima pengertian, realistis, kritis, sehingga diharapkan ada perubahan tingkah laku dalam menjaga kebersihan gigi dan mulutnya setelah diberikan penyuluhan dengan metode ceramah maupun bermain.

\section{Tujuan Penelitian}

Untuk mengetahui efektifitas metode ceramah dan metode bermain dalam penyuluhan kesehatan gigi dan mulut terhadap pengetahuan tentang kesehatan gigi dan mulut anak-anak sekolah dasar.

\section{Manfaat penelitian}

1. Hasil penelitian ini diharapkan dapat dimanfaatkan sebagai bahan masukan dalam perencanaan UKGS dan pelayanan penyuluhan kesehatan gigi dan mulut di SD N 064026 jln. Bunga Ganyong Medan Tuntungan.
2. Hasil penelitian ini diharapkan dapat meningkatkan kesadaran siswa/i sekolah dasar terhadap kesehatan gigi dan mulut.

3. Hasil penelitian ini diharapkan dapat menjadi sumber bagi penelitian selanjutnya dan sebagai bahan referensi di perpustakaan Jurusan Keperawatan Gigi Medan.

4. Hasil penelitian ini diharapkan dapat menambah pengetahuan bagi pembaca dan khususnya bagi penulis.

\section{Hipotesis}

Ada perbedaan skor pengetahuan kesehatan gigi dan mulut sebelum dan sesudah mendapatkan penyuluhan kesehatan gigi dan mulut dengan metode ceramah dan metode bermain.

\section{METODE PENELITIAN}

\section{Jenis Dan Desain Penelitian}

Dalam penelitian ini jenis penelitian yang dilakukan adalah eksperimen semu (quasi eksperiment) dengan metode pre and post test grup design. Dalam penelitian ini murid-murid dibagi atas dua kelompok yaitu satu kelompok diberi penyuluhan dengan metode ceramah dan satu kelompok lagi diberi penyuluhan dengan metode bermain dalam meningkatkan pengetahuan tentang kesehatan gigi dan mulut pada siswa/i kelas V SD N. 064026 Jln. Bunga Ganyong Kelurahan Baru Ladang Bambu Medan Tuntungan.

\section{Populasi Dan Sampel Penelitian}

Menurut Soekidjo Notoadmojo bahwa populasi adalah keseluruhan subjek penelitian. Populasi dalam penelitian ini adalah seluruh siswa/i di SD N. 064026 Jln. Bunga Ganyong Kelurahan Baru Ladang Bambu Medan Tuntungan Tahun 2013 jumlah populasi pada penelitian ini adalah 521 orang siswa.

Sampel adalah sebagian yang diambil dari keseluruhan objek yang akan diteliti dianggap mewakili seluruh populasi (Arikunto: 2006). Sampel penelitian ini adalah seluruh siswa/i kelas V SDN. 064026 Jln. Bunga Ganyong Kelurahan Baru Ladang Bambu Medan Tuntungan yang berjumlah 60 orang siswa/i.

\section{HASIL DAN PEMBAHASAN}

\section{Hasil Penelitian}

\subsection{Analisis Univariat}

Data yang dikumpulkan adalah data hasil penelitian yang dilakukan terhadap siswa/i SD N 064026 Jln. Bunga Ganyong Kelurahan Baru Ladang Bambu, Medan Tuntungan Tahun 2014. Penelitian langsung dilakukan kepada siswa/i dengan memberikan dua kali penyuluhan yaitu penyuluhan dengan metode ceramah dan metode bermain yang menjada sampel. Dari penelitian yang telah dilakukan maka, skor pengetahuan sebelum dan sesudah dilakukan penyuluhan dengan metode ceramah maupun bermain ada perbedaan. Setelah data terkumpul, dibuatlah 
analisis data dengan cara membuat tabel distribusi frekuensi untuk masing-masing kelompok sampel. Kemudian dilakukan pengolahan data statistik yaitu dengan mengunakan Uji t-Tes

Tabel 1. Distribusi Frekuensi Skor Pengetahuan Sebelum Penyuluhan Dengan Metode Ceramah Siswa/I Kelas V SD N 064026 Tahun 2014.

\begin{tabular}{lcc}
\hline \multicolumn{1}{c}{ Katagori } & N & Proporsi (\%) \\
\hline Baik & 18 & 60 \\
Sedang & 12 & 40 \\
Buruk & 0 & 0 \\
\hline \multicolumn{1}{c}{ Jumlah } & 30 & 100 \\
\hline
\end{tabular}

Dari tabel di atas menunjukkan tingkat pengetahuan sisiwa/i sebelum penyuluhan dengan metode ceramah, menunjukkan yang berpengetahuan baik sebanyak 18 orang (60\%), yang berpengetahuan sedang sebanyak 12 orang (40\%) dan tidak ada yang berpengetahuan buruk.

Tabel 2. Distribusi Frekuensi Skor Pengetahuan Sesudah Penyuluhan Dengan Metode Ceramah Siswa/I Kelas V SD N 064026 Tahun 2014.

\begin{tabular}{lcc}
\hline \multicolumn{1}{c}{ Katagori } & N & Proporsi (\%) \\
\hline Baik & 24 & 80 \\
Sedang & 6 & 20 \\
Buruk & 0 & 0 \\
\hline \multicolumn{1}{c}{ Jumlah } & 30 & 100 \\
\hline
\end{tabular}

Dari tabel di atas menunjukkan bahwa tingkat pengetahuan sisiwa/i sesudah penyuluhan dengan metode ceramah, menunjukkan yang berpengetahuan baik naik menjadi 24 orang (80\%) sedangkan yang berpengetahuan sedang turun menjadi 6 orang (20\%) dan tidak ada yang berpengetahuan buruk.

Tabel 3. Distribusi Frekuensi Skor Pengetahuan Sebelum Penyuluhan Dengan Metode Bermain Siswa/I Kelas V SD N 064026 Tahun 2014.

\begin{tabular}{lcc}
\hline \multicolumn{1}{c}{ Katagori } & N & Proporsi (\%) \\
\hline Baik & 19 & 63,34 \\
Sedang & 11 & 36,66 \\
Buruk & 0 & 0 \\
\hline \multicolumn{1}{c}{ Jumlah } & 30 & 100 \\
\hline
\end{tabular}

Dari tabel di atas menunjukkan tingkat pengetahuan sisiwa/i sebelum penyuluhan dengan metode bermain, menunjukkan yang berpengetahuan baik sebanyak 19 orang (63,34\%), sedangkan yang berpengetahuan sedang sebanyak 11 orang (36,66\%) dan tidak ada yang berpengetahuan buruk.
Tabel 4. Distribusi Frekuensi Skor Pengetahuan Sesudah Penyuluhan Dengan Metode Bermain Siswa/I Kelas V SD N 064026 Tahun 2014.

\begin{tabular}{lcc}
\hline \multicolumn{1}{c}{ Katagori } & N & Proporsi (\%) \\
\hline Baik & 30 & 100 \\
Sedang & 0 & 0 \\
Buruk & 0 & 0 \\
\hline \multicolumn{1}{c}{ Jumlah } & 30 & 100 \\
\hline
\end{tabular}

Dari tabel di atas menunjukkan tingkat pengetahuan sisiwa/i sebelum penyuluhan dengan metode bermain, menunjukkan yang berpengetahuan baik sebanyak 30 orang (100\%), sedangkan yang berpengetahuan sedang menurun menjadi 0 dan tidak ada yang berpengetahuan buruk.

Tabel 5. Distribusi Frekuensi Rata-Rata Skor Pengetahuan Sebelum dan Sesudah Penyuluhan Dengan Metode Ceramah Dan Bermain Siswa/I Kelas V SD N 064026 Tahun 2014.

Metode penyuluhan

Pengetahuan

\begin{tabular}{lcc}
\cline { 2 - 3 } & Sebelum & Sesudah \\
\hline Ceramah & 10,87 & 13 \\
\hline Bermain & 11,07 & 14,3 \\
\hline
\end{tabular}

Dari tabel di atas dapat kita ketahui rata-rata skor pengetahuan sebelum dan sesudah penyuluhan dengan metode ceramah dan bermain, sebelum dilakukan penyuluhan dengan metode ceramah rata-rata skornya adalah 10,87 sedangkan sesudah dilakukan penyuluhan dengan metode ceramah rata-rata skornya adalah 13 . Sebelum penyuluhan dengan metode bermain skor rataratanya adalah 11,07 dan setelah dilakukan penyuluhan dengan metode bermain skornya adalah 14,3.

Tabel 6. Distribusi Frekuensi Selisih Rata-Rata Skor Pengetahuan Sebelum Dan Sesudah Dilakukan Penyuluhan Dengan Metode Ceramah Dan Bermain Siswa/I Kelas V SD N 064026 Tahun 2014.

\begin{tabular}{lcc}
\hline Metode Penyuluhan & N & $\begin{array}{c}\text { Selisih rata-rata } \\
\text { skor (mean) }\end{array}$ \\
\hline Ceramah & 30 & 2,13 \\
\hline Barmain & 30 & 3,23 \\
\hline
\end{tabular}

Dari tabel di atas dapat kita ketahui bahwa selisih rata-rata skor pengetahuan sebelum dan sesudah dilakukan penyuluhan kesehatan gigi dan mulut dengan metode ceramah dan bermain adalah, penyuluhan dengan metode ceramah 2,13 sedangkan untuk metode bermain adalah 3,23 dari hasil ini dapat disimpulkan bahwa penyuluhan kesehatan gigi dan mulut dengan metode bermain lebih baik dibandingkan dengan metode ceramah. 


\subsection{Analisis Bivariat}

Analisis bivariat dalam penelitian ini dimaksudkan untuk melihat ada atau tidaknya perbedaan antara hipotesis dengan tujuan peneliti sebenarnya. Setelah dilakukan Uji statistik maka hasil Uji dinyatakan ada perbedaan secara statistik karna apabila $\mathrm{p}<0,05$ maka Ho ditolak yang artinya ada perbedaan yang bermakna, hasil Uji mendapatkan nilai p0,016; $<<0,05$.

\section{Pembahasan}

Pada siswa/i kelas V SD N 064026 Jln. Bunga Ganyong Medan Tuntungan menunjukan rata-rata skor pengetahuan sebelum dilakukan penyuluhan kesehatan gigi dan mulut dengan metode ceramah adalah 10,87 dan bermain adalah 11,07 ini menunjukkan bahwa tingkat pengetahuan tentang kesehatan gigi dan mulut pada siswa/i SD N 064026 sudah baik.

Nilai rata-rata skor pengetahuan sesudah penyuluhan kesehatan gigi dan mulut dengan metode ceramah adalah 13 dan bermain adalah 14,3 kemudian dari hasil Uji statistik menunjukan selisih skor rata-rata antara metode ceramah dan bermain sebesar 2,13 dan 3,23 secara statistik ada perbedaan yang bermakna (p0,016), hal ini membuktikan bahwa penyuluhan kesehatan gigi dan mulut dengan metode ceramah maupun bermain dapat memberikan efek meningkatkan pengetahuan siswa/i namun penyuluhan kesehatan gigi dan mulut dengan metode bermain lebih memiliki nilai tambah dan lebih efektif digunakan pada anak-anak karena dengan bermain anak-anak mampu mengembangkan imajinasi, potensi yang ada dalam dirinya, anak-anak akan lebih senang dan menjadikannya lebih aktif (Sudono A, 2000). Belajar dan bermain juga akan memberikan kesempatan kepada anak untuk memanipulasi, mengulang-ulang, menemukan sendiri, bereksplorasi serta mempraktekkannya (Sugianto M,1995).

Hasil penelitian ini membuktikan bahwa penyuluhan kesehatan gigi pada anak-anak lebih baik dilakukan dengan metode bermain. Hal ini juga dibuktikan oleh Makuch, 2001, bahwa metode bermain dapat meningkatkan pengetahuan anak lebih baik dibandingkan dengan metode ceramah. Penelitian yang dilakukan oleh Fuller, 2001, pada anak-anak SD di Inggris menunjukkan bahwa metode bermain telah menjadi pelopor kesehatan secara lisan dalam promosi kesehatan gigi dan mulut. Oleh penelitian Rusli, 2003, pada murid-murid SD St. Paulus kelas III dan V Jakarta Barat, peningkatan pengetahuan sebelum dan sesudah penyuluhan dengan metode bermain secara statistik ada perbedaan bermakna ( $\mathrm{p}=0,0001)$.

Hasil penelitian yang dilakukan oleh Haqqy Mardiah Universitas Sumatra Utara 2010 kepada siswa/i SD Islam An-Nizam Medan juga menunjukkan adanya perbedaan yang bermakna secara statistik $(\mathrm{p}=0,001)$.

Hal ini membuktikan bahwa penyuluhan kesehatan gigi dan mulut dengan metode bermain lebih baik dari pada penyuluhan kesehatan gigi dan mulut dengan mengunakan metode ceramah.

\section{SIMPULAN DAN SARAN}

\section{A. Simpulan}

1. Rata-rata skor pengetahuan sebelum dilakukan penyuluhan kesehatan gigi dan mulut dengan metode ceramah dan bermain adalah 10,87 dan 11,07 ini menunjukkan bahwa tingkat pengetahuan tentang kesehatan gigi dan mulut pada siswa/i SD N 064026 sudah baik.

2. Nilai rata-rata skor pengetahuan sesudah penyuluhan kesehatan gigi dan mulut dengan metode ceramah dan bermain adalah 13 dan 14,3 .

3. hasil Uji statistik menunjukan selisih skor rata-rata antara metode ceramah dan bermain sebesar 2,13 dan 3,23 secara statistik ada perbedaan yang bermakna $\mathrm{p}(0,016)$, hal ini membuktikan bahwa penyuluhan kesehatan gigi dan mulut dengan metode ceramah maupun bermain dapat memberikan efek meningkatkan pengetahuan siswa/i, penyuluhan kesehatan gigi dan mulut dengan metode bermain lebih memiliki nilai tambah dan lebih efektif digunakan pada anak-anak sekolah dasar.

B. Saran

1. Disarankan agar penyuluhan kesehatan gigi dan mulut pada anak-anak lebih baik dilakukan dengan metode bermain dari pada metode ceramah karena dengan bermain proses belejar mengajar menjadi lebih aktif dan lebih menyenangkan sehingga cocok digunakan pada anak-anak.

2. Diharapkan adanya dukungan dari pihak sekolah untuk membuat program Usaha Kesehatan Gigi Sekolah (UKGS) sehingga dokter atau perawat gigi dapat berperan aktif dalam mengedukasi dan mengontrol kesehatan gigi dan mulut para siswa/i dan akhirnya menimbulkan kebiasaan yang baik dalam merawat kesehatan gigi dan mulutnya.

\section{DAFTAR PUSTAKA}

Arikunto S, 2007. Prosedur penelitian, Reneka cipta. Jakarta.

Budiharto, 1998. Pendidikan Kesehatan Gigi. Staff Pengajar Ilmu Kesehatan Gigi Masyarakat Fakultas Kedokteran Gigi. Jakarta.

Departemen Kesehatan RI, 1999. Upaya Kesehatan Gigi Masyrakat (UKGM). Departemen Kesehatan RI Direktorat Jenderal Pelayanan Medik Direktorat Kesehatan Gigi. Jakarta.

Desmita, 2005. Psikologi perkembangan. PT Remaja Rosdakarya. Bandung.

Fuller SS, 2001 The development of national oral health promotion programme for preschool children in England. Int Dent J. 
Gondhoyoewono T, 1997. Peranan psikologi dan komunikasi pada program kesehatan gigi dan mulut. Majalah Kedokteran Gigi FKG USAKTI. Jakarta.

Good TL, Jere EB, 1990. Educational psychology a realistic approach, Ed. Ke-4. New York: LongMan.

Haqqy Mardhiah, 2010. Universitas Sumatra Utara, Medan.

Lorinda B dkk, 2001. Interviewing children about real and events: revisiting the narrative elaboration procedure. USA:Whittier Collage.

Makuch A, Recshke K.2001. Playing games in promoting childhood dental health. Patient Education and Counseling. Int Dent J.

McSharry G, Sam J, 2000. Role playing in science teaching and learning. School Science Review.

Rusli M, Gondhoyoewono T, 2003. Pengaruh metode bermain terhadap penyuluhan kesehatan gigi dan mulut ( the effect of role playing method to dental health education . Fakultas Kedokteran Gigi. Jakarta.

Samsunuwiyati, 2010 Perkembangan anak, Perkembangan Fisik, Perkembangan Motorik, Perkembangan Kognitif, Perkembangan Psikososial. http://www.g-excess.com/id/ perkembangan-anak-perkembangan-fisikmotorik-kognitif-psikososial.html

Soekidjo Notoadmojo, 2005. Metode penelitian. Reneka cipta. Jakarta.

Sudono A, 2000. Sumber belajar dan alat permainan. PT Grasindo. Jakarta.

Sugianto M, 1995. Bermain, mainan dan permainan. Departemen Pendidikan dan Kebudayaan. Jakarta.

Suryosubroto B, 2002. Proses belajar mengajar di sekolah. PT. Rineka Cipta. Jakarta. 